\title{
Accidentally ingested textile foreign bodies, a cause of gastrointestinal obstruction in dogs and cats - a retrospective study
}

DOI: 10.35530/IT.072.06.1851

NICULAE TUDOR

MARIO DARIUS CODREANU

BOGDAN ALEXANDRU VIȚĂLARU

CARMEN MIHAI

VLAD TRAIAN LUPU

\author{
ABSTRACT - REZUMAT \\ Accidentally ingested textile foreign bodies, a cause of gastrointestinal obstruction in dogs and cats - a \\ retrospective study
}

Gastrointestinal obstruction is a life-threatening condition that is usually caused by accidental ingestion of inedible objects, through play or food indiscretions. Ingested foreign objects generate the mechanical obstruction of the gastrointestinal segment, characterized by a relatively typical set of symptoms, depending on the location. The aim of this study was the clinical and imaging description of some cases of gastrointestinal obstruction in dogs and cats, caused by swallowing textile foreign bodies. The study included 12 dogs and 8 cats of different breeds and ages, belonging to both sexes, which showed clinical signs suggestive from a clinical-anamnestic point of view for gastrointestinal obstruction. These patients had symptoms with acute or chronic progressive evolution of the gastrointestinal tract, including restlessness, deviation, vomiting (single or repeated episodes), abdominal tenderness, constipation and tenesmus. The diagnosis was confirmed by radiographic examination, simple and with contrast medium, and ultrasound, completed in some situations with laparotomy. Ingested textile foreign bodies were represented by socks/stockings (5 dogs and 3 cats), underwear (3 dogs), rope (1 dog and 3 cats), carpet fragments (2 dog and 1 cat), toy fragments (1 dog and 1 cat), and they were located in the stomach (7/12; 58.33\%, respectively 4/8; 50\%), in the gastro-duodenal segment (2/12; $16.67 \%$, respectively $3 / 8 ; 37.5 \%)$, in the jejunum (3/12; $25 \%$, respectively $1 / 8 ; 12.5 \%)$ and in the colon (1/12; $8.33 \%$, respectively $1 / 8 ; 12.5 \%)$. Gastrointestinal obstruction in pets, caused by accidental ingestion of textile foreign bodies, is a medical emergency and imaging examinations are the main diagnostic tool in the establishment of a subsequent therapy with maximum efficiency.

Keywords: cat, dog, foreign bodies, textile

Corpii străini textili ingerați accidental, cauză de obstrucție gastrointestinală la câini și pisici - un studiu retrospectiv

Obstrucția gastrointestinală este o afecțiune care poate pune viața animalelor în pericol, obișnuit cauzată de ingestia accidentală a unor obiecte necomestibile, din joacă sau din cauza indiscrețiilor alimentare. Obiectele străine ingerate produc obstrucția mecanică a segmentului gastrointestinal, caracterizată de un ansamblu simptomatologic relativ caracteristic, în funcție de localizare. Scopul acestui studiu a fost descrierea clinică și imagistică a unor cazuri de obstrucție gastrointestinală la câine și la pisică, determinată de înghițirea corpilor străini de natură textilă. În studiu au fost incluși 12 câini și 8 pisici de rase și vârste diferite, aparținând ambelor sexe, care au prezentat semne clinice sugestive clinico-anamnetice pentru obstrucția gastro-intestinală. Acești pacienți au prezentat simptome cu evoluție progresivă acută sau cronică ale tractului gastro-intestinal, incluzând neliniște, abatere, vomă (unică sau repetată), sensibilitate abdominală, constipație și tenesme. Diagnosticul a fost confirmat prin examen radiografic, fără și cu mediu de contrast, și ecografic, completat în unele situații cu laparatomie. Corpii străini textili ingerați au fost reprezentați de șosete/ciorapi (5 câini și 3 pisici), lenjerie de corp (3 câini), sfoară (1 câine și 3 pisici), fragmente de covor (2 câine și 1 pisică), fragmente de jucării (1 câine și 1 pisică), iar localizarea lor a fost înregistrată la nivelul stomacului (7/12; $58,33 \%$, respectiv 4/8; 50\%), gastro-duodenal (2/12; 16,67\%, respectiv 3/8; 37,5\%), jejunului (3/12; 25\%, respectiv $1 / 8$; $12,5 \%)$ și colonului (1/12; 8,33\%, respectiv 1/8; 12,5\%). Obstrucția gastrointestinală la animalele de companie, cauzată de ingestia accidentală a corpurilor străine de natură textilă, reprezintă o urgență medicală, iar examenele imagistice reprezintă principalul instrument de diagnostic în orientarea terapeutică ulterioară cu maximă eficiență.

Cuvinte cheie: pisică, câine, corpi străini, materiale textile

\section{INTRODUCTION}

In veterinary practice, accidental ingestion of foreign bodies is one of the causes leading to medical visits [1-4]. This phenomenon is reported incidentally after ingestion during play or due to food indiscretions, being encountered in both young and adult animals [1]. Ingested foreign bodies can pass through the digestive tract without causing any damage, patients remaining asymptomatic, but large and irregularly shaped foreign bodies can hinder the digestive transit and may cause partial or total obstruction [2, 3, 5]. Mechanical gastrointestinal obstruction is a lifethreatening condition and it is characterized by a relatively typical set of symptoms, depending on the 
location and type of the ingested foreign body $[1,2,6]$. These bodies can vary in nature, including among their ranks bones, stones, wood, leather, fruit kernels, metals, plastics, but also textiles (non-linear and linear) $[3,4,7]$. Romania is one of the largest textile producers, supplying on the clothes market, the carpet market, and the market of textiles and fibres used in various economic sectors [8]. The aim of this study was the clinical and imaging description of some cases of gastrointestinal obstruction in dogs and cats caused by swallowing textile foreign bodies.

\section{MATERIALS AND METHODS}

A retrospective analysis was performed based on the synthetic evaluation of the medical records of the patients visiting in the Clinic of the Faculty of Veterinary Medicine in Bucharest, displaying suggestive signs for gastrointestinal obstruction during 2019-2021. Patient identification data (dogs and cats) were obtained, including breed, age and sex, as well as the medical history and clinical signs displayed. Patients who received a clinical examination supplemented with an abdominal imaging examination, represented by radiographic examination (using a DuraDiagnost F30 machine, Philips, China) and/or ultrasound examination (using a MyLab Six, Esaote, UK device) were included in the study. In some situations, contrast radiography was used to confirm the diagnosis of gastrointestinal obstruction, obtaining multiple images, orthogonally, at appropriate time intervals, according to classical protocols [9].

Depending on the signs expressed by the patients, respectively on the location of the gastrointestinal obstruction as established by the imaging examination, they were referred to a medical treatment (purging, enema or inducing vomiting) or to surgery. The Surgical treatment was performed on anesthetized patients, using, as appropriate, laparoscopic-gastrointestinal enterotomy and/or enterectomy in accordance with existing protocols $[10,11]$.

\section{RESULTS AND DISCUSSIONS}

The current study included 12 dogs and 8 cats, of different breeds and ages, belonging to both sexes (table 1), which displayed clinical signs of gastrointestinal obstruction.

For 9 dogs and 7 cats, the owners provided information on the textile nature of the ingested objects because they observed the animals playing with them and later discovered the items missing, while for the rest of the animals ( 3 dogs and 1 cat), the owners were unable to provide any data on the possible ingestion of foreign bodies. During the clinical examination, the animals displayed gastrointestinal symptoms with acute or chronic progressive evolution, identified as restlessness (8 dogs and 6 cats),

\begin{tabular}{|c|c|c|c|c|c|}
\hline \multicolumn{6}{|c|}{ PATIENTS INCLUDED IN THE STUDY } \\
\hline No. & Breed & Age (months) & Sex* $^{*}$ & Identified foreign body & Localization \\
\hline \multicolumn{6}{|c|}{ Dogs (no.=12) } \\
\hline 1 & Crossbreed & 72 & $\mathrm{~m}$ & Sock & stomach \\
\hline 2 & Cocker spaniel & 36 & $\mathrm{f}$ & Stocking & jejunum \\
\hline 3 & Crossbreed & 120 & $\mathrm{f}$ & Underwear & stomach \\
\hline 4 & Crossbreed & 42 & $f$ & Toy fragments & stomach \\
\hline 5 & French Bulldog & 36 & $\mathrm{~m}$ & Stocking & stomach \& jejunum \\
\hline 6 & Bichon & 132 & $\mathrm{~m}$ & Underwear & gastro-duodenal segment \\
\hline 7 & Crossbreed & 7 & $\mathrm{~m}$ & Rope & gastro-duodenal segment \\
\hline 8 & Golden retriever & 54 & $\mathrm{~m}$ & Carpet fragments & jejunum \\
\hline 9 & Basset & 84 & $\mathrm{f}$ & Underwear & stomach \\
\hline 10 & Bichon & 24 & $\mathrm{~m}$ & Sock & stomach \\
\hline 11 & German Shepherd & 36 & $\mathrm{~m}$ & Carpet fragments & colon \\
\hline 12 & Boxer & 24 & $f$ & Sock & stomach \\
\hline \multicolumn{6}{|c|}{ Cats (no. $=8$ ) } \\
\hline 13 & Ragdoll & 36 & $\mathrm{~m}$ & Toy fragments & stomach \\
\hline 14 & European shorthair & 48 & $\mathrm{~m}$ & Sock & stomach \\
\hline 15 & European shorthair & 108 & $f$ & Rope & gastro-duodenal segment \\
\hline 16 & Persian & 84 & $f$ & Carpet fragments & colon \\
\hline 17 & Persian & 96 & $\mathrm{~m}$ & Sock & stomach \& jejunum \\
\hline 18 & European shorthair & 22 & $\mathrm{~m}$ & Rope & gastro-duodenal segment \\
\hline 19 & European shorthair & 14 & $f$ & Sock & stomach \\
\hline 20 & Siamese & 24 & $\mathrm{~m}$ & Rope & gastro-duodenal segment \\
\hline
\end{tabular}

Note: ${ }^{*} \mathrm{~m}=$ male; $\mathrm{f}=$ female. 


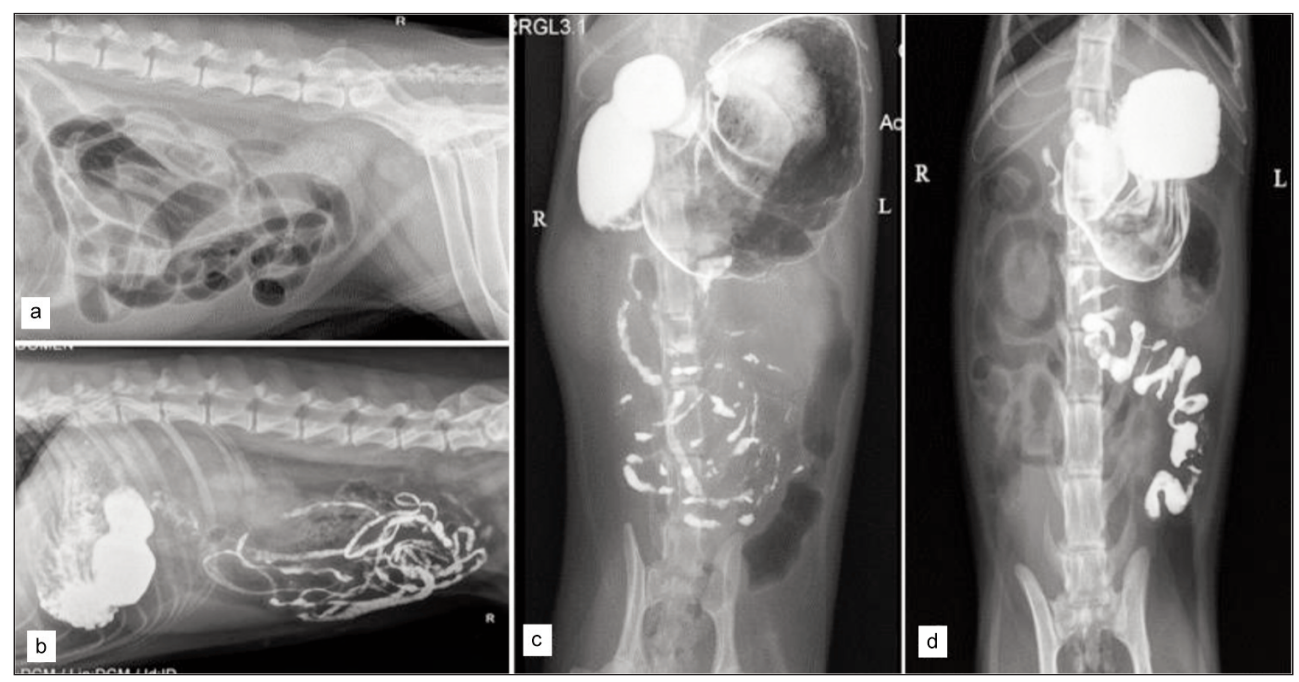

Fig. 1. Simple radiographic examination with contrast medium of the abdomen: a - right side view, showing gas-dilated intestinal loops and an area with high density, inhomogeneous, in the terminal part of the colon (textile foreign body and dehydrated feces) (case 11); $b$ - right lateral view and $c$ - ventro-dorsal view, with contrast medium showing gastric dilation and the persistence of the contrast substance at the level of the pylorus (non-linear textile foreign body) (case 6); $d$ - ventro-dorsal view, with contrast medium showing the pleated duodenal segment (linear foreign body) (case 15)

view, according to previous indications [9]. Thus, changes and radiographic signs were observed that confirmed the presence of foreign bodies in the gastrointestinal segment, including delayed emptying of the stomach (9 dogs and 8 cats) and the presence of thin postobstruction contrast medium (6 dogs and 5 cats) (figure $1, b$ and $c)$, the pleating of the intestinal loops in the proximal intestinal segment $(1 \mathrm{dog}$ and 3 cats) (fig. $1, d$ ), or the blocking of the intestinal contrast medium (3 dogs and 2 cats). In

deviation (4 dogs and 2 cats), vomiting (unique episodes in 3 dogs and 2 cats, and repeated episodes in 9 dogs and 5 cats), distension and abdominal tenderness ( 3 dogs and 2 cats), constipation and tenesmus ( 2 dogs and 1 cat). To confirm the diagnosis of mechanical gastrointestinal obstruction, simple abdominal radiographs were performed on all animals, aiming at the discovery of gastrointestinal changes, such as mechanical ileus (figure 1,a), but these were not always conclusive. Therefore, other diagnostic methods were used, such as radiographic examination with contrast medium, obtaining a series of images from the left side, right side and with ventro-dorsal

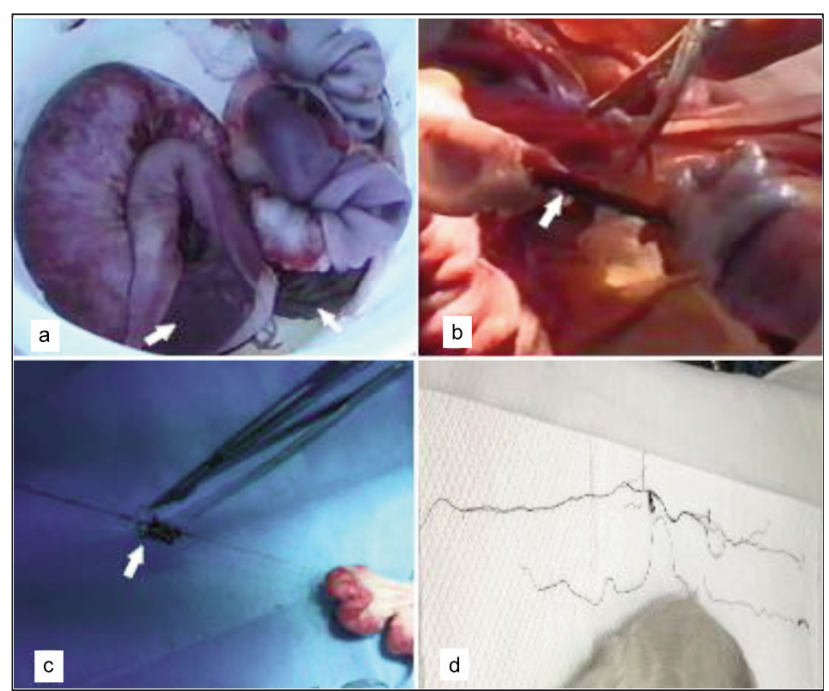

Fig. 2. Extracted foreign bodies: a - segmental jejunum resection following invagination caused by the presence of a sock (arrows) (case 5); $b$ - non-linear textile foreign body (sock - arrow) at the intestinal level (case 2); $c$ - linear foreign body (string - arrow) (case 15); $d$ - rope extracted from the stomach of a Siamese cat, 2-year-old male (case 20) addition, the ultrasound examination, performed on 6 dogs and 5 cats, showed pyloric obstruction ( 3 dogs and 3 cats), segmental intestinal dilation ( 2 dogs) and the pleating of bowel loops (1 cat), and for the rest of the patients ( 1 dog and 3 cats). 1 cat) the signs were inconclusive. Following the clinical and imaging examination, it was possible to locate the foreign bodies along the gastrointestinal tract: at the level of the stomach $(7 / 12 ; 58.33 \%$, respectively $4 / 8 ; 50 \%)$, in the gastro-duodenal segment $(2 / 12 ; 16.67 \%$, respectively $3 / 8 ; 37.5 \%)$, in the jejunum $(3 / 12 ; 25 \%$, respectively $1 / 8 ; 12.5 \%)$ and in the colon $(1 / 12$; $8.33 \%$; respectively $1 / 8 ; 12.5 \%$ ). It should be noted that, in a dog and a cat, foreign bodies were present in both the stomach and the jejunum. In the case of 2 dogs (case 1 and case 10), because the owners immediately went to the clinic with the animal and were able to provide information about what had happened before (ingesting a baby sock), they resorted to inducing vomiting, the animals being able to eliminate the ingested foreign body. Also, one cat (case 13), which came to the clinic with repeated vomiting, spontaneously vomited fragments of a textile toy after the clinical examination, and the radiographic images obtained did not show signs of gastrointestinal obstruction. In one patient (case 11), due to the location of the obstruction in the terminal segment of the digestive tract, repeated enema and fragmentation by forceps of a "plug", containing carpet threads mixed with dehydrated feces and dry grass threads, were used. In the other cases (9 dogs and 7 cats), the foreign bodies were removed after performing the exploratory laparotomy, gastro- and enterotomy. It should be mentioned that in case 5 , due to the presence of the textile foreign body, invagination and local necrosis of the intestinal wall occurred, which required the resection of the respective segment 
(figure 2,a). Foreign bodies removed from the patients included in this study were represented by socks/stockings (5 dogs and 3 cats) (figure 2,b), underwear/panties (3 dogs), rope (1 dog and 3 cats) (figure 2,c), carpet fragments (2 dogs and 1 cat), toy fragments (1 dog and a cat) (table 1).

Pets, including dogs and cats, can accidentally ingest various objects that are not usually part of their daily diet, including inedible objects such as textiles. The ingestion of foreign bodies can occur through play, incidental in young animals due to age-specific exuberance [2, 12], but can also be found in adult animals [4]. The ingestion of textiles may also be the consequence of perverted taste [13] or their impregnation with food odours [14], as evidenced by the history of some cases in the current study. The examined patients examined were aged between 7 months and 11 years in dogs, with an average of 4.63 years, respectively 14 months and 9 years, with an average of 4.5 years in the case of cats, the results being consistent with those described in the field literature [2, 4]. Regarding the breed of animals included in the study, as shown in table 1 , half-breeds $(4 / 12 ; 33.33 \%)$ in the case of dogs and the common European breed (4/8; $50 \%$ ) in the case of cats were the most affected. Previous studies have shown an obvious heterogeneity of the races in which accidental ingestion of foreign bodies was diagnosed [1-2, 6], and the differences may be the consequence of the different number of patients included in the study, but also of the existing population diversity.

Pathogenetic lesions are dependent on the type of foreign body accidentally ingested, linear (which remains fixed in a point of the digestive tract, causing distal intestinal folding) or non-linear/discrete (which does not cause bowel loops) [3]. The results of our investigations indicated the presence of both non-linear textile foreign bodies ( $91.67 \%$ of dogs and $62.5 \%$ of cats, respectively) and of linear textile foreign bodies ( $8.33 \%$ of dogs, respectively $37.5 \%$ of cats), similar to those previously published $[2,4,6]$. In general, foreign bodies ingested by animals and reaching the gastrointestinal tract may cause partial or total obstruction of the lumen, depending on their size [1-5, 12]. However, most of the time, the total obstruction is the result of the presence of solid foreign bodies with large dimensions and no holes, which block the intestinal transit, appearing radiographically as "filling defects" in the contrast medium column, causing dilation of the gastrointestinal segment and accumulation of the contrast substance before the obstruction [9]. In the case of textiles, the radiographic aspects are distinctly different from those found in foreign bodies of another nature, because textiles do not appear as "filling defects", but absorb the contrast medium (acting like a sponge) which they gradually release when the peristaltic wave passes, thus determining the appearance of the post-obstruction "thin wire" contrast medium. In the current study, it was found that non-linear foreign bodies caused a relative total obstruction of the gastrointestinal lumen, while linear foreign bodies caused folding of the affected segment. Both are typical aspects and they are highlighted accordingly on contrast radiographic images.

The clinical picture and imaging aspects are directly correlated with the time elapsed since the ingestion of foreign bodies and their location along the digestive tract [6]. For the patients included in this study, their localization is comparable to that described in some previous studies [4], but different from others [2]. It was observed that the stomach (pyloric antrum) and the gastroduodenal segment represent the main location, followed by the jejunal segment, in both dogs and cats. This can be attributed to the fact that, in most cases, patients came to the clinic immediately after the ingestion of foreign bodies, which did not migrate too much along the intestinal tract, an idea supported by the preponderance of acute clinical signs and the absence of severe complications. The ultrasound and the radiographic examinations with contrast medium, through the accuracy and diagnostic significance, constitute a true imaging method for assessing the parietal integrity, respectively the destruction of the specific parietal architecture. Although the presence of linear foreign bodies is associated with an increased rate of morbidity and mortality in patients due to the degree of compromise of the intestinal wall $[2,7]$, no severe changes were found in our study, which can be attributed to the rapid intervention in case management. However, in 2 cases, during surgery, jejunitis (inflammation of the jejunum wall) and invagination with necrosis of the intestinal wall were observed, which required the resection (enterectomy) of that segment.

Textiles accidentally ingested by pets are a real danger to their lives through gastrointestinal obstruction and parietal destruction. Previous studies have suggested that the severity of clinical signs and the risk of necrosis and intestinal perforation may be correlated with the type of material ingested (linear or nonlinear), but also with the time elapsed from the ingestion to the medical intervention [2, 15], which requires an intervention as soon as possible to remove them. In the current study, the patients' recovery was complete, without the occurrence of secondary complications, including for those who underwent surgery.

\section{CONCLUSIONS}

Our investigations have highlighted the involvement of a wide range of textile foreign bodies in the production of gastrointestinal obstruction, both in dogs and cats.

The incidence of ingestion of foreign bodies of nonlinear textile origin was $91.67 \%$ in dogs and $62.5 \%$ in cats, all occurrences being attributed to food indiscretions.

Gastrointestinal obstruction in pets is a medical emergency, and imaging examinations are the main diagnostic tool that allows for appropriate therapeutic guidance in the effective resolution of those cases. 


\title{
REFERENCES
}

[1] Gianella, P., Pfammatter, N.S., Burgener, I.A., Oesophageal and gastric endoscopic foreign body removal: complications and follow-up of 102 dogs, In: Journal of Small Animal Practice, 2009, 50, 649-654, http://doi: 10.1111/j.1748-5827.2009.00845.x

[2] Hayes, G., Gastrointestinal foreign bodies in dogs and cats: a retrospective study of 208 cases, In: Journal of Small Animal Practice, 2009, 50, 576-583, http://doi: 10.1111/j.1748-5827.2009.783.x

[3] Hobday, M.M., Pachtinger, G.E., Drobatz, K.J., Syring, R.S., Linear versus non-linear gastrointestinal foreign bodies in 499 dogs: clinical presentation, management and short-term outcome, In: Journal of Small Animal Practice, 2014, 55, 560-565, http://doi: 10.1111/jsap.12271

[4] Caixeta, A.C.F., Alves, E.G.L., Coelho, N.G.D., Souza, A.C.F., Torres, R.C.S., Nepomuceno, A.C., Foreign body in the gastrointestinal tract of dogs: a retrospective study, In: Ars Veterinaria, 2018, 34, 1, 20-24, http://dx.doi.org/10.15361/2175-0106.2018v34n1p20-24

[5] Papazoglou, L.G., Patsikas, M.N., Rallis, T., Intestinal foreign bodies in dogs and cats, In: Compendium on Continuing Education for the Practicing Veterinarian, 2003, 25, 1, 830-843

[6] Madany, J., Milczak, A., Wrześniewska, K., Balastegui Martinez, M.T., Diagnostic of gastrointestinal obstruction in dogs and cats using ultrasound - a retrospective study of 38 cases, In: Medycyna Weterynaryjna, 2020, 76, 4, 212-215, http://doi: dx.doi.org/10.21521/mv.6386

[7] Mullen, K.M., Regier, P.J., Ellison, G.W., Londoño, L., The pathophysiology of small intestinal foreign body obstruction and intraoperative assessment of tissue viability in dogs: a review, In: Topics in Companion Animal Medicine, 2020, 40, 100438, http://dx.doi.org/10.1016/j.tcam.2020.100438

[8] Aileni, R.M., Chiriac, L., Surdu, L., Rădulescu, R.I., Field research and methodologies for textile industry innovation in the context of European economy, In: Industria Textila, 2020, 71, 1, 12-16, http://doi: 10.35530/IT.071.01.1623

[9] Holloway, A., McConnell, F., BSAVA Manual of Canine and Feline Radiography and Radiology: A Foundation Manual, British Small Animal Veterinary Association, Chichester, UK, 2013, 74-108

[10] Costea, R., Anesteziologie, Ed. Printech, București, 2017

[11] Leau, T., Manual de chirurgie operatorie veterinară, Ed. Printech, București, 2009

[12] Mahesh, V., Jyothi Shree, S., Lathamani, V.S., Nagaraja, B.N., Surgical retrieval of foreign body in dog - a case report, In: International Journal of Sciences, Environment and Technology, 2019, 8, 5, 1044-1048

[13] Vlăgioiu,C., Tudor, N., Semiologie, Ed. Sitech, Craiova, Romania, 2012, 58-88

[14] Sharma, A.K., Singh, S.K., Bidyabhusan, Sneha, K., Stomach foreign bodies in Labrador dog and its surgical management - a case report, In: Exploratory Animal and Medical Research, 2017, 7, 2, 227-229

[15] Maxwell, E.A., Dugat, D.R., Waltenburg, M., Upchurch, D., Soto-Elias, P., Duffy, D.J., Spector, D., Petrovsky, B., Payton, M., Outcomes of dogs undergoing immediate or delayed surgical treatment for gastrointestinal foreign body obstruction: a retrospective study by the Society of Veterinary Soft Tissue Surgery, In: Veterinary Surgery, 2020, 1-9, http://doi: 10.1111/vsu.13520

\section{Authors:}

\section{NICULAE TUDOR ${ }^{1}$, BOGDAN ALEXANDRU VIȚĂLARU ${ }^{1}$, VLAD TRAIAN LUPU ${ }^{1,2}$, MARIO DARIUS CODREANU ${ }^{1}$, CARMEN MIHAI ${ }^{3}$}

\author{
${ }^{1}$ University of Agronomic Sciences and Veterinary Medicine, Faculty of Veterinary Medicine, \\ Department of Clinical Sciences, 105 Splaiul Independenței Street, 5 District, 050097, Bucharest, Romania \\ e-mail: nghtudor@yahoo.com, vladlupu@hotmail.com, codveterinary@yahoo.com \\ 2Link-vet Veterinary Clinic, 359 Șoseaua Pantelimon Street, Bucharest, Romania \\ e-mail: vladlupu@hotmail.com \\ ${ }^{3}$ National Research Development Institute for Textiles and Leather, \\ 16, Lucretiu Patrascanu Street, Bucharest, Romania \\ e-mail: carmen.mihai@incdtp.ro
}

\section{Corresponding author:}

BOGDAN ALEXANDRU VIȚĂLARU

e-mail: alexandrumv@yahoo.com 